\section{Journal of Anatolian Environmental and Animal Sciences \\ (Anadolu Çevre ve Hayvancılık Bilimleri Dergisi) \\ Doi: https://doi.org/10.35229/jaes.486354}

\title{
Known and newly recorded Gymnodamaeid mites (Acari, Oribatida, Gymnodamaeidae) \\ from Kizılcahamam, Turkey ${ }^{[*]}$
}

\author{
Şule BARAN
}

Department of Biology, Faculty Arts and Sciences, Sakarya University, Sakarya /TURKEY. (D): https://orcid.org/0000-0003-2497-5876

How to cite: Baran, S. (2019). Known and newly recorded Gymnodamaeid mites (Acari, Oribatida, Gymnodamaeidae) from Kızılcahamam, Turkey. J. Anatolian Env. and Anim. Sciences, 4(1), 7-10. Doi: https://doi.org/10.35229/jaes.486354

Atıf yapmak için: Baran, Ş. (2019). Türkiye'de, Kızılcahamam'dan yeni kaydedilen Gymnodamaeid akarları (Acari, Oribatida, Gymnodamaeidae). Anadolu Çev. ve Hay. Dergisi, 4(1), 7-10. Doi: https://doi.org/10.35229/jaes.486354

Abstract: Gymnodamaeid mites collected from Kizılcahamam district are evaluated from systematic viewpoint to contribute to the knowledge of the Turkish soil mite fauna. Two species were recorded namely: Gymnodamaeus bicostatus (Koch, 1835) and Joshuella meyeri (Bayartogtokh and Schatz, 2009) from an old pine forest. The first species was formerly recorded from Erzurum and Bolu provinces of Turkey, the second species is recorded from Turkey for the first time outside the type locality (Austria) in the world.

Keywords: Acari, Oribatida, Gymnodamaeidae, new record, Kızılcahamam, Turkey.

Türkiye’de, Kızılcahamam'dan yeni kaydedilen Gymnodamaeid akarları (Acari, Oribatida, Gymnodamaeidae)

Öz: Türkiye toprak akarı faunasına katkı sağlamak amacıyla Kızılcahamam ilçesinden Gymnodamaeid akarlar toplanmıştır. Eski bir çam ormanından Gymnodamaeus bicostatus (Koch, 1835) ve Joshuella meyeri (Bayartogtokh and Schatz, 2009) türleri kaydedilmiş olup bunlardan ilki daha önce Türkiye'nin Erzurum ve Bolu illerinden bilinmektedir, ikinci tür ise dünyada tip yeri (Avusturya) dışında ilk kez Türkiye'den kaydedilmiştir.

Anahtar sözcükler: Acari, Oribatida, Gymnodamaeidae, yeni kayıt, Kızılcahamam, Türkiye. 


\section{INTRODUCTION}

Oribatid mites are a group of Acari which live especially in the upper layer of the soil and then leaf litter, mosses, lichens, and other low plants. They have an ecological importance because they break down the organic residue and add nutrients back to the soil. By this way living plants pull the nutrients back into their roots and grow. Soil mites are also serve as food source for soil predators such as small salamanders, beetles, ants, centipedes, larger mites, spiders, and others (Hoy, 2008). More than 10,000 oribatid mite species with in 163 family, 1278 genera and subgenera known all over the world (Subias, 2004, 2018 update).

Gymnodamaeid mites are more restricted to the Northern Hemisphere and diverse in the continental climates including grasslands, alpine and tundra soils, and dry patches of soil, litter, and moss (Bayartogtokh, 2001; Woas, 1992; Walter, 2009). These mites are characterized by well sclerotized and completely coated with layer of thick cerotegument usually with a distinctive pattern on notogaster, separate genital and anal apertures with anogenital bridge, tridactylous legs (Walter, 2009; Hugo, 2010).

As a result of our studies on Gymnodamaeid mites of Kiz1lcahamam district totally two species were recorded from an old pine forest, namely: Gymnodamaeus bicostatus (Koch, 1835) and Joshuella meyeri (Bayartogtokh \& Schatz, 2009). The first species was formerly recorded from Erzurum and Bolu provinces of Turkey Yalçın et al., 2013; Toluk \& Ayyld1z, 2014), the second species is recorded from Turkey for the first time outside the type locality (Austria).

\section{MATERIALS and METHODS}

Field studies were carried out in old pine forests of Kiz1lcahamam district, October 2016. Leaf litter and soil samples were transferred into a laboratory in nylon bags. Mites were extracted form the soil samples by a Tullgren funnel apparatus. Mites were fixed and stocked in $70 \%$ ethanol and slide fixed in modified Hoyer's medium on temporary cavity slides.

Terminology and taxa identification were according to Balogh and Balogh, (1992) and Weigmann, (2006).

\section{RESULTS and DISCUSSION}

Genus Gymnodamaeus Kulczynski, 1902: Syn: Donjohnstonella Walter, 2009; Heterodamaeus Ewing, 1917; Johnstonella Paschoal, 1983; Odontodamaeus Paschoal, 1982; Pleodamaeus Paschoal, 1983 (Subías, 2004).

Gymnodamaeus bicostatus (Koch, 1835) (Figs. 1-2)

Syn: Eremaeus asperulus Berlese, 1882.

\section{Redescription.}

Material Examined: Turkey, Ankara, Kizilcahamam distict, 40³7'22.1" N 32²7'07.0" E, 1529 m,
29 October 2016, soil and litter samples from an old pine forest $(\mathrm{n}=7)$.

Measurements: Body 645-670 $\mu \mathrm{m}$ in length, 367$378 \mu \mathrm{m}$ in width, sensillus (ss) 159-166 $\mu \mathrm{m}, h 1$ about 20-22 $\mu \mathrm{m}, h_{2}$ about $67-71 \mu \mathrm{m}$ in length( $\left.\mathrm{n}=7\right)$.

Integument: Colour dark brown.

Prodorsum: Rostrum rounded. Sensillus with long stalk and flattened fusiform head, interlamellar setae robust but very short, positioned on the front interbothridial region.

Notogaster: Center of notogaster with two paralel ridge connected to each other at the back and two pairs of short protrusions laterally. Notogaster with granulated cerotegument on surface. Only five pairs of notogastral setae present $\left(h_{1}, h_{2}, p_{1}-p_{3}\right) . h_{1}$ and $h_{2}$ are covered with cerotegumet and setae $h_{1}$ posteriotlydirected, setae $h_{2}$ directed to sides. Setae $p_{1-3}$ orginating on the ventral border of notogaster.

Ventral region: Anal and genital plates big and close to each other. Two pairs of anal, two pairs of adanal, one pair of aggenital and seven pairs of genital setae present. Epimeral seta formula as 3-1-3-3.

The distribution: Holarctic region (Subías, 2004, 2018 update).

Turkey locality: Erzurum and Bolu (Yalçın et al., 2013; Toluk \& Ayyıldız, 2014)

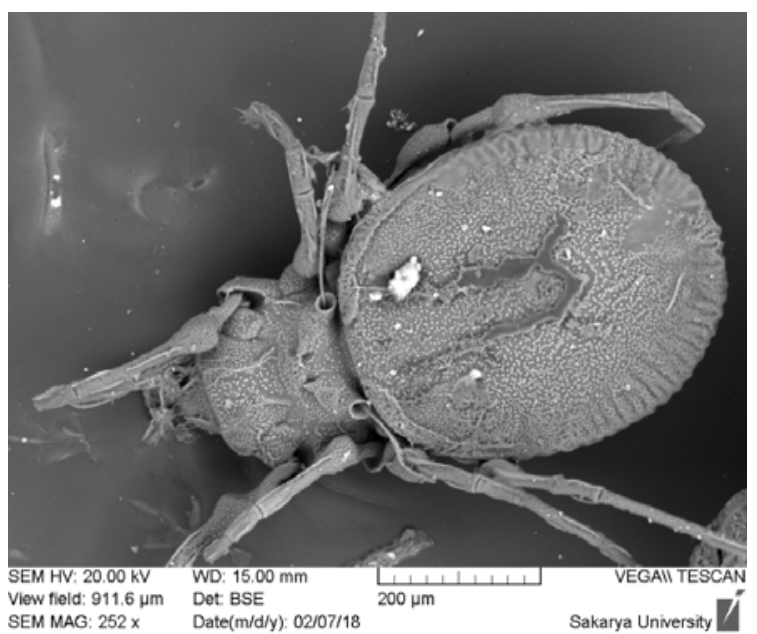

Figure 1. Gymnodamaeus bicostatus (Koch, 1835), dorsal view.

Genus Joshuella Wallwork, 1972: Nortonella Paschoal, 1982; Paschoalia Özdikmen, 2008;

Roynortonella Walter, 2009.

Joshuella meyeri (Bayartogtokh \& Schatz, 2009), (Fig. 3)

Redescription

Material Examined: Turkey, Ankara, Kiz1lcahamam district, 40³7'22.1" N 32²7'07.0" E, 1529 m, 29 October 2016, soil and litter samples from an old pine forest $(n=2)$. 
Measurements: Body 500-509 $\mu \mathrm{m}$ in length, 289$293 \mu \mathrm{m}$ in width, sensillus (ss) $88-93 \mu \mathrm{m}, h_{2} 110-112 \mu \mathrm{m}$ in length $(\mathrm{n}=2)$.

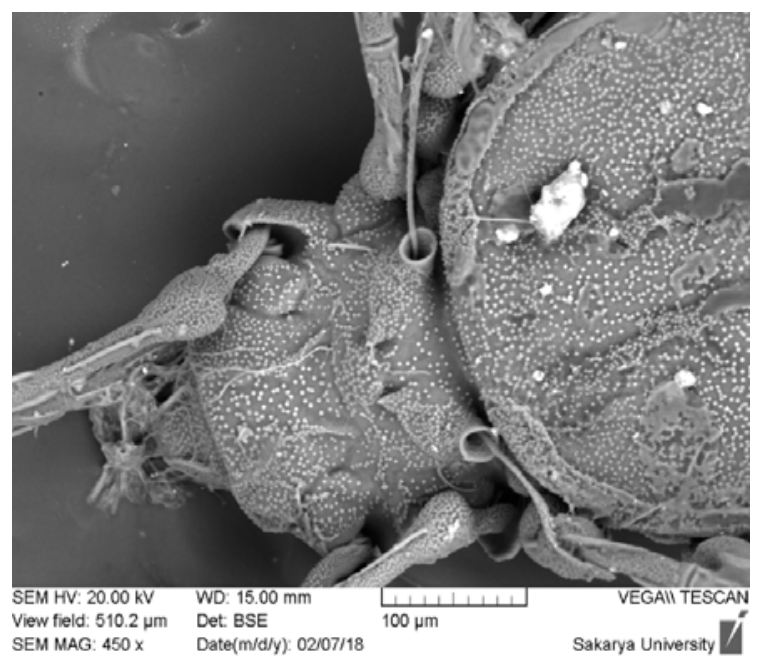

Figure 2. Gymnodamaeus bicostatus (Koch, 1835), prodorsum.

Integument: Colour brown.

Prodorsum: Rostrum rounded. Sensillus with thin stalk and dilated and elongated head, interlamellar setae (in) very small, positioned on the inner sides of bothridia.

Notogaster: Notogastral surface with three central hexagonal ridges connected to each other. Three pairs of lateral short protrusions extend from the central hexagonal ridges and one pairs of posterior protrusion extend from the behind. Notogaster with granulated cerotegument on surface. Only five pairs of notogastral setae $\left(h_{1}, h_{2}, p_{1}, p_{2}, p_{3}\right)$ present and covered with cerotegumet. Setae $h_{2}$ is the longest one $(112 \mu \mathrm{m})$ and anteriorly directed. Rest of the notogastral setae posteriorly directed and curved.

Ventral region: Anal and genital plates big and separated from each other. Two pairs of anal, two pairs of adanal, one pair of aggenital and six or seven pairs of genital setae. Epimeral seta formula as 3-1-3-3.

Distributed in Austria, firstly recorded in Turkey and secondly recorded in the world.

In this study, we redescribed Gymnodamaeid mites collected from Kızılcahamam district; Gymnodamaeus bicostatus and Joshuella meyeri.

The second species Joshuella meyeri differs from the other species of genus by; typical chitinous ornamentation of on prodorsum and notogaster. Joshuella meyeri is previously only recorded from type locality; Austria from pine forest at $1060 \mathrm{~m}$. This is the second record of Joshuella meyeri in the world. Our specimens were also recorded from pine forest at $1529 \mathrm{~m}$. Bayartogtokh and Schatz (2009) reported that this species prefers dry habitats, our data also supports this finding.

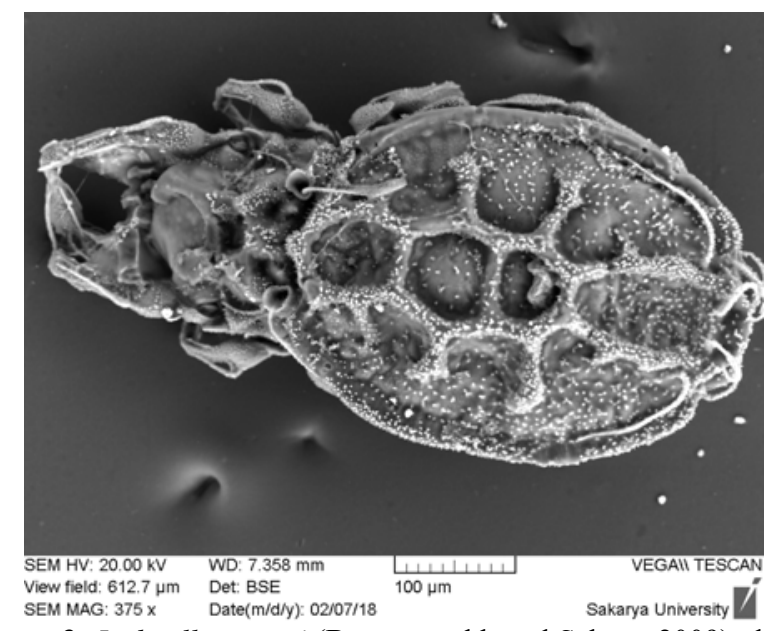

Figure 3. Joshuella meyeri (Bayartogtokh and Schatz, 2009), dorsal view.

\section{ACKNOWLEDGEMENTS}

I wish to thank Department of Metallurgical and Materials Engineering and Thermal Spray Covering and Research Laboratory (SAÜ-TESLAB) for the Scanning Electron Microscopy investigations.

\section{REFERENCES}

Bayartogtokh, B. (2001). Bayartogtokh B. 2001. A new and a little known species of gymnodamaeid mites (Acari: Oribatida: Gymnodamaeidae) from Mongolia. Edaphologia, 67, 37-47.

Bayartogtokh, B. \& Schatz, H. (2009). Two new species of the genus Gymnodamaeus (Acari:Oribatida: Gymnodamaeidae) fromTyrol (Austria), with remarks on diversity and distribution of the known species. Revue Suisse de Zoologie. 116,1-21.

Balogh, J. \& Balogh, P. (1992). The Oribatid mites genera of the World 2. Hungarian National Musueum Press, $375 \mathrm{pp}$.

Hugo, E.A. (2010). Two new species of Gymnodamaeidae (Acari: Oribatida) from South Africa. Internat $J$ Acarol, 36(3), 199-21.

Hoy, M.A. (2008). Soil Mites (Acari: Oribatida and Others). In: Capinera J.L. (eds) Encyclopedia of Entomology. Springer, Dordrecht.

Subías, S. (2004). Subias, L. S., 2004. Listado sistematico, sinonimico y biogeografico de los acaros oribatidos (Acariformes: Oribatida) del Mundo (Excepte fosiles). Graellsia 60: 3-305 (actualizado en junio de 2006, en abril de 2007, en mayo de 2008, en abril de 2009 , en julio de 2010, en febrero de 2011, en abril de 2012, en mayo de 2013 y en febrero de 2014, en marzo de 2015, en febrero de 2016 y en febrero de 2017 y en enero de 2018). 
Toluk, A. \& Ayyıldız, N. (2014). Gymnodamaeus Kulczynski, 1902 (Acari, Oribatida, Gymnodamaeidae) türleri üzerine bir çalışma. Bitki Koruma Bülteni, 54, 171-179.

Walter, D.E. (2009). Genera of Gymnodamaeidae (Acari: Oribatida: Plateremaeoidea) of Canada, with notes on some nomenclatorial problems. Zootaxa, 2206, 23-44.

Weigmann, G. (2006). Hornmilben (Oribatida) Die Tierwelt Deutschlands, Begründet 1925 von Friedrich Dahl 76. Teil. Goecke \& Evers, Keltern, 520 pp.

Weigmann, G. \& Mourek, J. (2008). Contribution to the Central European Gymnodamaeus species $G$. barbarossa and G. bicostatus (Acari, Oribatida, Gymnodamaeidae), Zoosyst Evol, 84(2), 255-264.
Woas, S. (1992). Beitrag zur revision der gymnodamaeidae grandjean, 1954 (Acari, Oribatei). Andrias, 9, 21161.

Yalçın, S., Doğan, S. \& Ayyıldız, N. (2013). Uzunoluk Ormanında (Erzurum) yaşayan bazı oribatid akarlar (Acari: Oribatida) ve onlardan izole edilen mikrofunguslar. Türkiye Entomoloji Dergisi, 37 (1), 117-131.

\section{*Corresponding author's:}

Şule BARAN

Department of Biology, Faculty Arts and Sciences, Sakarya University, Sakarya /TURKEY

E-mail: sbaran@sakarya.edu.tr

ORCID: https://orcid.org/0000-0003-2497-5876 